International Journal of Advanced Biological and Biomedical Research Available online at http:www.ijabbr.com

Volume 7, Issue 4 (2019) pp. 370-380

DOI:10.33945/SAMI/IJABBR.2019.4.8

Original Article

\title{
Heamatology, Serum Biochemistry, Relative Organ Weight and Bacteria Count of Broiler Chicken Given Different Levels of Luffa Aegyptiaca Leaf Extracts
}

\author{
J.0. Alagbe \\ Department of Animal Nutrition, Sumitra Research Farm, Gujarat, India \\ *Corresponding Author E-mail: demsonfarms@yahoo.com
}

Received: 20 April 2019, Revised: 20 June, Accepted: 23 June 2019

\begin{abstract}
The objective of this study was to evaluate the heamato-biochemical, relative organ weight and bacteria count of broiler chicken given different levels of Luffa aegyptiaca leaf extract (LUF). A total of 250 day old Ross 308 broiler chicks of mixed sex were divided into five treatments, each group was further divided into five replicates each of ten (10) birds in a completely randomized design. Birds in treatment A were given $1.20 \mathrm{~g} /$ litre of Neomycin in water, treatment B, C, D and E were given 5, 10, 15 and $20 \mathrm{~mL} /$ litre of LUF. Clean feed and water was given ad libitum and the experiment lasted for 3 weeks. The obtained data was used to evaluate the haematological parameters (PCV, RBC, Hb, WBC, MCV, MCH and MCHC), serum biochemical indices (Albumin, globulin, calcium, phosphorus, SGPT and SGOT) and organ weight (liver, kidney, spleen, heart, lungs, pancreas and small intestine) and bacteria count (E. coli and Lactobacillus). The obtained results revealed that there were no significant differences $(p>0.05)$ in the haematological, relative organ weight, serum biochemical parameters and E.coli count. However, there was a significant difference $(\mathrm{p}<0.05)$ in the Lactobacillus count among the group. It was concluded that LUF could be given to broilers at $20 \mathrm{~mL} /$ litre without any deleterious effect on the blood profile and general performance of the animal.
\end{abstract}

Key words: Luffa aegyptiaca extract, Broilers, Haematology, Organ weight, Bacteria count.

\section{Introduction}

Medicinal plant is any plant which, in one or more of its organs, contains substances that can be used for therapeutic purposes or be regarded as precursors for the synthesis of useful drugs (Sofowora, 1993). Recently, there has been an increasing demand for organic or natural products to reduce or eliminate the use of antibiotics as growth promoters due to their high cost and negative human health issue of antibiotic resistance (Hassan, 2007). There have also been concerns on the contamination of animal products which made the European Union in 2006 to ban the use of antibiotics as growth promoters in livestock feed. Plants (herbs and spices) are therefore botanical alternatives to antibiotics because they possess phytochemicals or secondary metabolites. Phytochemicals also regarded as phytobiotics are a natural bioactive compound that are derived from plants and incorporated into animal feed or water as extract to enhance 
productivity through the improvement of digestibility, nutrient absorption and elimination of pathogens resident in the animal gut (Rios and Recio, 2005; Sokovic et al., 2010; Levic et al., 2011; Rajasekaran et al., 2013; Gadde et al., 2017). Plant extracts are used in animal nutrition as appetite and digestion stimulants, stimulants of physiological functions and treatment of certain pathological conditions, colourants and antioxidants (Tamara et al., 2009). According to (Lina Šernaite, 2017) plants have the ability to synthesize secondary metabolites such as phenol, phenolic acids, flavones, flavonoids, flavonols, quinones, tannins, saponins, alkaloids and phytate. Phenolic compounds have been reported to exhibit antimicrobial and antioxidant activity (Martins et al., 2015), steroids have been reported to have antimicrobial and antifungal activity (Martins et al., 2015) and stimulation of bone marrow and growth. Saponins have been reported to perform antioxidant role and are useful in vaccine production (Asl and Hosseinzadeh, 2008). Flavonoids and tannin have been suggested to play a key role as antibacterial, antifungal, antidiarrheal and antioxidant (Adisa et al., 2010). Alkaloids have been shown to have antipyretic activity (Faizi et al., 2008).

Previous studies have been carried out on the use of plant extracts and their level of inclusion in the water of broilers, for instance, citrus sinensis peel extract (Abbas Ebrahimi et al., 2014; Akbarian, 2013; Pourhossein et al., 2012), Morigold flower extract (Nuraini et al., 2017; Skrivan et al., 2016), Turmeric extract (Nuraini et al., 2019; green tea extract (Farahat, 2016; El-deek et al., 2012; Khalaji et al., 2011; Shahid et al., 2013), Neem leaf extract (Biu et al., 2009; Chakravarty and Pasad, 1991; Nagalakshmi et al., 1996), Moringa olifera leaf extract (Alabi et al., 2017; Khan et al., 2017; Faluyi and Agbede, 2018). Yet, there is a dearth of information on the use of Luffa aegyptiaca extracts on the heamato-biochemical and bacterial count of broilers.

There is a correlation between nutrition and immune response, an animal that is not properly managed will undergo stress, poor health and finally death during serious conditions. Hence, the presented study is focused to investigate the effect of Luffa aegyptiaca leaf extracts on the haematology, serum biochemistry and bacteria count of broiler chicken.

\section{Materials and methods}

\section{Experimental site}

The experiment was carried out at Division of Animal Nutrition, Sumitra Research Farm, Gujarat, India during the month of January to March, 2019.

\section{Collection and processing of Luffa aegyptiaca leaves (LUF)}

Luffa aegyptiaca leaf was identified and authenticated by a botanist on the research farm. Thereafter, fresh disease free leaves of L. aegyptiaca were harvested from the farm, the leaves were thoroughly washed with running tap water to remove the debris and allowed to dry under shade for 11 days, and they were then hammer milled into L. aegyptiaca powder (LUF). The extract was prepared by soaking 200 grams of LUF in one litre of water and kept in an air tight plastic container and the mixture kept in the refrigerator at $4{ }^{\circ} \mathrm{C}$ for 48 hours and then sieved with a with cheese cloth, then with What Man No 1 filter paper $(24 \mathrm{~cm})$.

\section{Pre-experimental operations}

A deep litter poultry house was used for the experiment, the pen was swept, cleaned and well disinfected with Cid 2000, feed and water troughs were also washed. The electrical 
fittings (bulb) 200 watts were properly fixed and a vaccination programme was designed before the commencement of the study.

\section{Animal management and experimental set-up}

One day old 200 (Ross 308) broilers of mixed sex were obtained from a commercial hatchery in India. The chicks were weighed individually at the beginning of the experiment and wing banded. They were assigned into five treatments, each group was further divided into five replicates each of ten (10) birds. Anti-stress was added in the drinking water of the birds. The light (electric bulb) was continuous and the initial brooding temperature was $34{ }^{\circ} \mathrm{C}$ for the first week of age and it was gradually reduced by $2{ }^{\circ} \mathrm{C}$ per week. Vaccines were administered according to the prevailing vaccination schedule in the environment. Vitamins (Miavit) were added in water a day before and after each vaccination. Clean feed and water were provided unrestricted throughout the experimental period which lasted for 3 weeks.

Diets were formulated to meet the nutritional requirements of birds according to NRC (1994).

Treatment 1: $1.20 \mathrm{~g} /$ liter Neomycin (drinking water)

Treatment 2: $5.0 \mathrm{~mL} /$ liter of LUF

Treatment 3: $10 \mathrm{~mL} /$ liter of LUF

Treatment 4: $15 \mathrm{~mL} /$ liter of LUF

Treatment 5: $20 \mathrm{~mL} /$ liter of LUF

\section{Blood analysis}

At the end of the experiment, ten (10) birds were randomly selected from each treatment, two from each replicate for blood analysis. Blood was collected from the wing vein with a syringe and needle. Samples meant for hematology were put in tubes containing EDTA to prevent coagulation while those for serum biochemical parameters were put in bottles without EDTA. Hematological parameters covered pack cell volume (PCV), red blood cell (RBC), hemoglobin concentration (Hb), white blood cell (WBC), mean corpuscular volume (MCV), mean corpuscular hemoglobin $(\mathrm{MCH})$ and mean corpuscular hemoglobin concentration (MCHC). Serum parameters included albumin, globulin, total protein, cholesterol, calcium, phosphorus, serum glutamic oxaloacetate transaminase (SGOT) and serum glutamic pyruvate transaminase (SGPT). PCV, RBC, Hb, MCV, MCHC, WBC and its differentials were determined using standard techniques as reported by Jain (1986). The serum total protein, Albumin and Globulin were computed according to (Doumas and Briggs, 1972). Glutamic oxaloacetate transaminase (SGOT) and Glutamic phosphatase transaminase (SGPT) were determined according to Scott (1965).

\section{Carcass evaluation and bacteria count evaluation}

At the end of the $3^{\text {rd }}$ week, five birds were randomly selected per treatment; they were fasted overnight and given only water, weighed and slaughtered. After evisceration, the weight of the visceral organs and other parts of the birds were recorded. One gram of each sample of the jejunal content was collected and transferred into the test tube and was then diluted with $9 \mathrm{ml}$ of $1 \%$ peptone broth and homogenized. Counts of bacteria and lactobacillus were determined according to (Farmer 2003). 


\section{Laboratory analysis}

Phytochemical analysis was carried out on the plants leaf extract using standard methods Sofowora, 1993; AOAC, 2000). Percentage composition of flavonoids, saponin, phytate, alkaloids, tannin and oxalate were carried out according to procedures outlined by (Harbone, 1984; Boham and Kocipai-Abyazan, 1974). Mineral analysis was carried out using Atomic Absorption Spectrophotometer (AAS). Proximate analysis of crude protein, ash, ether extract and crude fibre in the experimental diet was carried out in accordance with the Association of Official Analytical Chemists (AOAC, 2000).

\section{Statistical analysis}

All data were analysed using (Snedecor and Cochran, 1989). The difference in treatment means was separated using Duncan's multiple range test as outlined by (Obi, 2002).

Table 1. Percentage composition of experimental diets (0-3 weeks)

\begin{tabular}{cc}
\hline Ingredients & Quantity \\
\hline Maize & 52.00 \\
Soya meal & 38.60 \\
Groundnut cake & 3.00 \\
Fish meal (72\%) & 1.00 \\
Bone meal & 3.00 \\
Limestone & 1.50 \\
Lysine & 0.15 \\
Methionine & 0.20 \\
Toxin binder & 0.01 \\
Premix & 0.25 \\
Salt & 0.30 \\
Total & 100.0 \\
\hline Calculated analysis & \\
ME (Kcal/kg) & 2801.9 \\
Crude protein (\%) & 23.23 \\
Ether extract (\%) & 6.11 \\
Crude fibre (\%) & 3.14 \\
\hline
\end{tabular}

* Premix supplied per kg diet :- Vit A, 10,000 I.U; Vit E, 5 mg; Vit D3, 3000I.U, Vit K, 3 mg; Vit B2, 5.5 mg; Niacin, 25 mg ; Vit B12, 16 mg ; Choline chloride, 120 mg ; Mn, 5.2 mg ; Zn, 25 mg ; Cu, 2.6 g ;

Folic acid, $2 \mathrm{mg}$; Fe, $5 \mathrm{~g}$; Pantothenic acid, $10 \mathrm{mg}$; Biotin, $30.5 \mathrm{~g}$; Antioxidant, $56 \mathrm{mg}$

Table 2. Phytochemical components of Luffa aegyptiaca leaf extract

\begin{tabular}{ccc}
\hline Parameters & \% Composition & Recommended safe \\
\hline Saponin & 6.22 & 7.02 \\
Flavonoids & 3.02 & 6.11 \\
Phytate & 1.01 & 11.33 \\
Alkaloids & 2.81 & 3.50 \\
Tannin & 3.11 & 31.20 \\
Oxalate & 1.01 & 1.30 \\
Phenol & 11.43 & - \\
\hline
\end{tabular}

Vikas Kumar et al., (2009) 
Table 3. Mineral composition of Luffa aegyptiaca leaf meal

\begin{tabular}{cc}
\hline Components & Quantity $(\mathbf{m g} / \mathbf{g})$ \\
\hline Calcium & 34.31 \\
Phosphorus & 0.12 \\
Potassium & 2.16 \\
Magnesium & 7.44 \\
Sodium & 0.31 \\
Manganese & 0.01 \\
Zinc & 0.001 \\
Iron & 0.03 \\
\hline
\end{tabular}

Table 4. Relative weight of internal organs of broilers given Neomycin and LUF

\begin{tabular}{|c|c|c|c|c|c|c|}
\hline \multirow[b]{2}{*}{ Parameters (g) } & \multicolumn{4}{|c|}{ Group } & \multirow[b]{2}{*}{ E } & \multirow[b]{2}{*}{ SEM } \\
\hline & A & B & C & D & & \\
\hline Heart & 3.51 & 3.47 & 3.44 & 3.57 & 3.50 & 0.34 \\
\hline Liver & 1.22 & 1.26 & 1.27 & 1.19 & 1.49 & 0.22 \\
\hline Pancreas & 2.26 & 2.27 & 2.22 & 2.24 & 2.26 & 0.18 \\
\hline Gizzard & 3.17 & 3.13 & 3.09 & 3.00 & 3.10 & 0.27 \\
\hline Proventriculus & 1.47 & 1.44 & 1.41 & 1.52 & 1.49 & 0.29 \\
\hline Intestine (cm) & 81.2 & 81.1 & 79.3 & 90.4 & 91.9 & 14.2 \\
\hline
\end{tabular}

Table 5. Bacteria and Lactobacillus count of broiler given Neomycin and LUF

\begin{tabular}{ccccccc}
\hline Parameter & A & B & C & D & E & SEM \\
\hline E. coli $($ cfu/g) & 22.11 & 21.81 & 21.26 & 21.17 & 21.11 & 6.77 \\
Lactobacillus & $10.44^{\mathrm{c}}$ & $17.44^{\mathrm{c}}$ & $20.44^{\mathrm{b}}$ & $20.51^{\mathrm{a}}$ & $20.73^{\mathrm{a}}$ & 4.11 \\
\hline
\end{tabular}

Table 6. Haematological parameters of broilers given Neomycin and LUF

\begin{tabular}{ccccccc}
\hline Parameters (g) & A & B & Group & D & E & SEM \\
\hline Pack cell volume (\%) & 29.22 & 29.88 & 30.01 & 30.67 & 31.71 & 1.31 \\
Haemoglobin (g/dl) & 11.51 & 12.13 & 12.61 & 12.98 & 13.11 & 1.34 \\
Red blood cell $(10)^{6} / \mu \mathrm{l}$ & 2.06 & 2.11 & 2.21 & 2.29 & 2.30 & 0.31 \\
MCV (fl) & 103.5 & 141.2 & 158.2 & 161.7 & 161.9 & 35.7 \\
MCH (pg) & 48.34 & 48.37 & 50.33 & 50.88 & 53.33 & 3.00 \\
MCHC \% & 39.67 & 40.61 & 41.58 & 41.77 & 42.01 & 2.91 \\
WBC $(10)^{6} / \mu \mathrm{l}$ & 19.31 & 20.21 & 20.89 & 21.12 & 21.56 & 2.07 \\
Heterophils (\%) & 6.13 & 7.02 & 7.23 & 8.10 & 8.15 & 0.47 \\
Monocytes (\%) & 0.89 & 0.94 & 1.02 & 1.10 & 1.12 & 0.21 \\
Lymphocytes (\%) & 9.04 & 9.31 & 9.51 & 9.64 & 9.85 & 0.45 \\
Eosinophils (\%) & 1.00 & 1.03 & 1.10 & 1.11 & 1.12 & 0.91 \\
\hline
\end{tabular}

a, b, c means being different superscripts in the same row are significantly different $(\mathrm{P}<0,05)$.

WBC- White blood cells; MCV - Mean corpuscular volume; MCH- Mean corpuscular haemoglobin; MCHC - Mean corpuscular haemoglobin concentration 
Table 7. Serum biochemical parameters of broilers given Neomycin and LUF

\begin{tabular}{|c|c|c|c|c|c|c|}
\hline \multirow[b]{2}{*}{ Parameters (g) } & \multirow[b]{2}{*}{$\mathbf{A}$} & \multicolumn{3}{|c|}{ Group } & \multirow[b]{2}{*}{$\mathbf{E}$} & \multirow[b]{2}{*}{ SEM } \\
\hline & & B & C & D & & \\
\hline Total protein $(\mathrm{g} / \mathrm{dl})$ & 3.45 & 3.61 & 3.63 & 3.65 & 3.68 & 0.25 \\
\hline Albumin (g/dl) & 1.83 & 1.87 & 1.90 & 1.91 & 1.95 & 0.24 \\
\hline Globulin (g/dl) & 1.62 & 1.74 & 1.73 & 1.74 & 1.73 & 0.25 \\
\hline Cholesterol (mg/l) & 68.1 & 68.3 & 65.1 & 65.3 & 65.1 & 8.72 \\
\hline Calcium (mg/l) & 6.91 & 6.98 & 7.13 & 7.61 & 7.71 & 2.01 \\
\hline Phosphorus (mg/l) & 4.01 & 4.13 & 4.32 & 4.33 & 4.41 & 1.10 \\
\hline SGPT (iu/l) & 33.1 & 30.6 & 30.1 & 28.4 & 28.1 & 2.34 \\
\hline SGOT (iu/l) & 63.2 & 61.4 & 59.3 & 58.1 & 55.1 & 3.21 \\
\hline
\end{tabular}

SGPT-Serum glutamic pyruvate transaminase

SGOT-Serum glutamic oxaloacetate transaminase

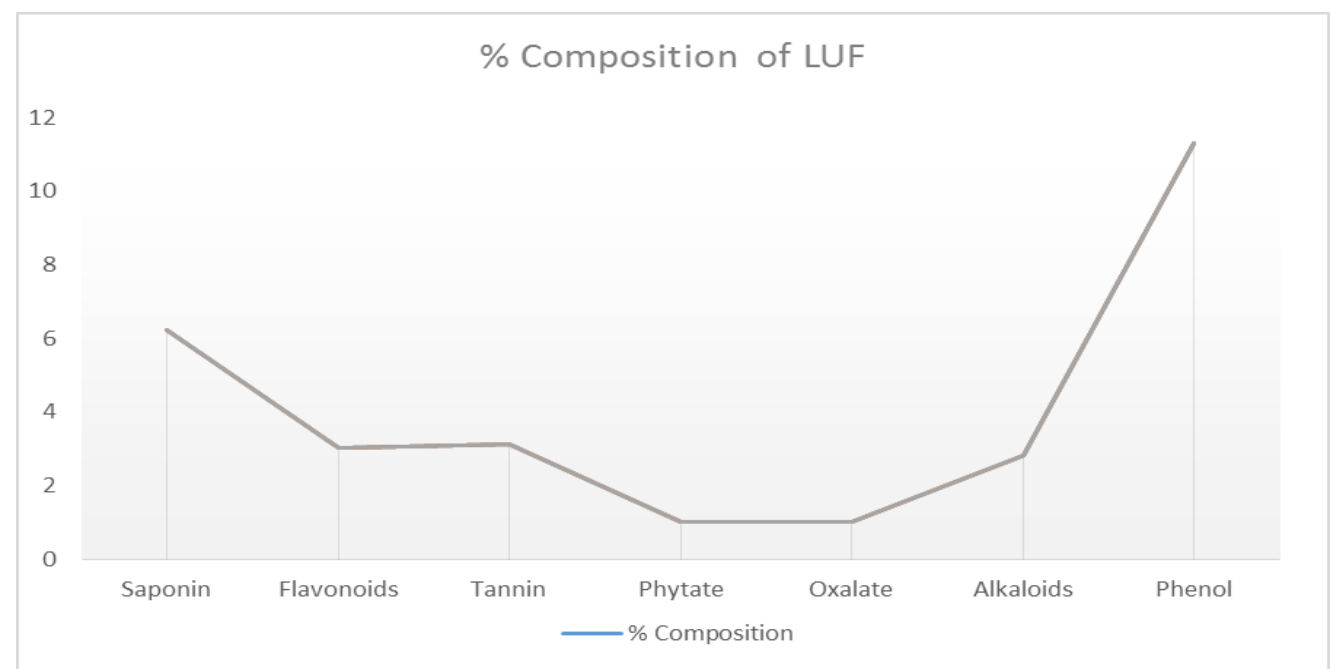

Figure 1. Phytochemical composition of LUF

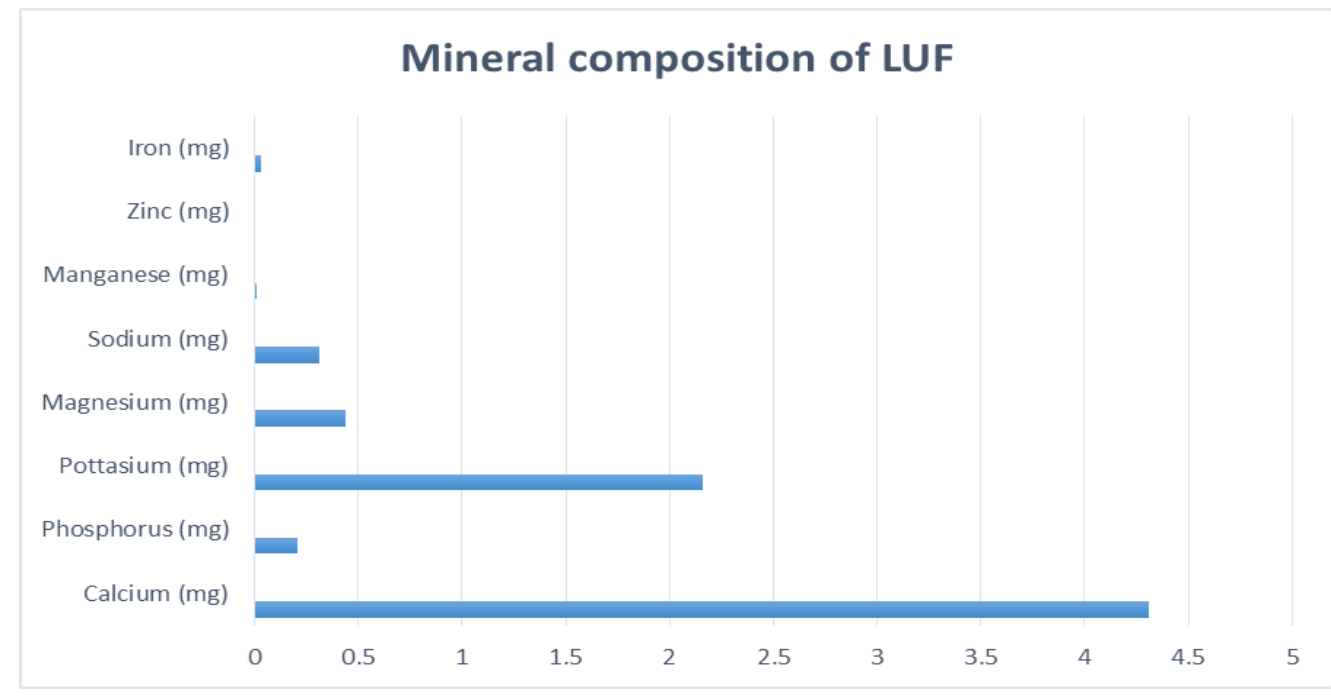

Figure 2. Mineral composition of LUF 


\section{Results and discussion}

Table 1 shows the percentage composition of experimental diet. The diets were formulated to meet the nutritional requirements of the animals according to (NRC, 1994) specifications. The result on the phytochemical analysis of LUF revealed the presence of several bioactive compounds at different concentrations as presented in Table 2. The phytochemical components are saponin, flavonoids, phytate, alkaloids, tannin, oxalate and phenol at $6.22 \%, 3.02 \%, 1.01 \%, 2.81 \%, 3.11 \%, 1.01 \%$ and $11.43 \%$ respectively. The result in the current study was consistent with the findings of (Shakeri et al., 2012; Jong et al., 2010; Mabhiza et al., 2016). However, all values falls within the safe recommended limit as proposed by (Vikas Kumar et al., 2009). According to (Igwe et al., 2010), alkaloid helped in repelling parasites and predators in plants and, when ingested at high level, could result in a negative effect on the thyroid stimulating hormone and some enzymes (Okaka et al., 1992). Flavonoids perform several functions such as antibacterial, antioxidant, antiinflammatory, anti-viral and anti-carcinogenic (Middleton et al., 2000).

The mineral composition of LUF revealed the followings: calcium (34.31 mg/g), phosphorus (0.12 mg/g), potassium (2.16 mg/g), magnesium $(7.44 \mathrm{mg} / \mathrm{g})$, sodium $(0.31 \mathrm{mg} / \mathrm{g})$, manganese $(0.01 \mathrm{mg} / \mathrm{g})$, zinc $(0.001 \mathrm{mg} / \mathrm{g})$ and iron $(0.03 \mathrm{mg} / \mathrm{g})$. Calcium had the highest quantity followed by magnesium, zinc had the lowest value, the result obtained in this experiment is contrary to the reports of (Alagbe Seyi Valerie et al., 2017) who recorded a higher value for calcium (58.6 mg/g) and magnesium (12.4 mg/g). The reported higher value can be attributed to differences in the variety of L. aegyptiaca leaf, environment and stage of growth of the plant before it was harvested. The presence of different minerals in LUF facilitates various physiological activities in animals. According to (Murray et al., 2000), minerals are structural components of the body tissues which are involved in the maintenance of acid base balance, regulation of body fluids, transport of gases and in muscle contractions.

Calcium plays a vital role in providing rigidity and support to animals (Ibrahim et al., 2001). Magnesium, zinc, iron and manganese are important co-factors found in the structure of certain enzymes and are indispensable in numerous biochemical pathways (Soetan et al., 2010).

The relative organ weights of broilers as given by Neomycin and LUF are presented in Table 4. The relative weights of heart, liver, pancreas, gizzard, proventriculus and intestine were not $(\mathrm{P}>0.05)$ significantly different among the groups. The weight of the heart ranged from 3.44-3.57 g, liver (1.26-1.49 g), pancreas (2.22-2.27 g), gizzard (3.00-3.17 g), proventriculus (1.41-1.52 g) and intestine (79.3-91.9 cm). According to (Madhusadha et al., 1986), antinutrients are causes of internal organs enlargement in birds. The non-significant differences in the organs' weight can be simply regarded as a reflection that the test materials are non-toxic. The results are in agreement with the findings of (Bolu et al., 2009) but contrary to the findings of (Nderi et al., 2014).

Table 5 revealed the bacteria and Lactobacillus count of broiler given by Neomycin and LUF. The bacteria count ranged from 21.11-22.11 (cfu/g) while those of lactobacillus ranged from 10.44-20.73 (cfu/g). There was a significant difference $(\mathrm{p}<0.05)$ in the E.coli count among the groups, the values slightly increased from group 1 to 2 before it eventually decreased though not at a significant rate. This was comparable to the findings of (AlMashhadani, 2014). There was no significant ( $p>0.05)$ difference in the lactobacillus count among the groups, thus acting as prebiotics. The current study is also in line with the 
findings of (Bird et al., 2002; Tiwari and Jyoti, 2008) who reported that Lactic acid bacteria produce several bactericidal/antibiotic like substances, which have been found to be effective against enteric pathogens. These bacteriocins can kill pathogenic bacteria, prevent colonization actions and also perform competitive exclusion which refers to the physical blocking of opportunistic pathogen (Watkins and Kratzer, 1983).

Haematological parameters of broilers given by Neomycin and LUF are presented in Table 6. The PCV values ranged from (29.22-31.71\%), Hb (11.51-13.11 g/dl), RBC (2.06-2.30 $\left.10^{6} / \mu \mathrm{l}\right), \mathrm{MCV}$ (103.5-161.9 fl), MCH (48.34-53.33 pg), MCHC (39.67-42.01\%), WBC $\left(19.3121 .5610^{6} / \mu \mathrm{l}\right)$, heterophils (6.13-8.15\%), monocytes (0.89-1.12\%), lymphocytes (9.04-9.85\%) and eosinophils (1.00-1.12\%). There were not significant ( $>>0.05)$ differences in all of the haematological parameters. In this sense, the haematological values slightly increased from group A to $\mathrm{E}$ but not at a significant level. The trend in the values could be as a result of intestinal microbial balance and a reflection that the animals were well nourished. However, all values are within the range reported by (Talebi et al., 2005; Islam et al., 2004). Changes in the RBC, MCH, MCHC and PCV values have been attributed to adaptation to adverse weather condition (Minka and Ayo, 2007), PCV and Hb variations which could also be linked to differences in the breed of animals (Adili and Melizi, 2013). The result obtained in the current study was consistent with the finding of (Akintomide et al., 2018) when neem leaf meal was fed to cockerels. (Adeyinka and Bello, 2013) also reported that WBC and its differentials helped to fight infections and produced antibodies to protect the body. Herbs, spices, and their extracts have high antioxidant capacity (Wojdylo et al., 2007).

The serum biochemical parameters of broiler chicken given by Neomycin and LUF revealed that albumin values ranged from (1.83-1.95 g/dl), globulin (1.62-1.83 g/dl), cholesterol (65.1-68.3 mg/l), calcium (6.91-7.71 mg/l), phosphorus (4.01-4.41 mg/l), SGPT (28.1-33.1 $\mathrm{mg} / \mathrm{l}$ ) and SGOT (55.1-63.2 mg/l). All the serum biochemical traits were not significantly ( $p>0.05$ ) among the groups. Albumin values in the blood can be easily influenced by protein shortage, the results obtained is an indication that the experimental diets contained enough protein to support the normal protein reserves across the group. The values for all the parameters fall within the normal range values established for birds by (Albokhadaim, 2012). Reports have also shown that when probiotic is supplemented in the diets broilers they tend to have lower total cholesterol, VLDL cholesterol and triglyceride concentrations in the serum.

\section{Conclusion}

It can be concluded from the experiment that LUF could be given to broilers at $20 \mathrm{ml} /$ litre without any deleterious effect on the blood profile and general performance of the animal. LUF has proven to play the significant role of a competitive exclusion i.e. physical blocking of opportunistic pathogen, thus maintaining a balanced gut microbial ecosystem making it a botanical alternative to antibiotics for use in organic poultry production.

\section{References}

Adili, N, Melizi, M. (2013). The effect of age, sex and altitude on the morphometry of red blood cells in small ruminants. J. Animal. Sci. Adv., 3(1):27-32. 
Akintomide, AA, Joseph, OG, Onibi, GE. (2016). Hematological and serum biochemistry of cockerels fed diets containing Neem leaf meal. Appl. Trop. Agr., 23:12-16.

Albokhadaim, I. (2012). Haematological and some biochemical values of indigenous chickens in Al-Ahsa, Saudi Arabia during summer season. Asian J. Poult. Sci., 6(4):138-145.

AOAC, (2000). Association of Official Analytical Chemist Official Method of Analysis $15^{\text {th }}$ Edition Washington, D.C. pages 70-88.

Bird, A, Croom, W, McBride, B. (2002). Dietary management of the intestinal microbiota using probiotics and prebiotics in human and animals. Proc. Aust. Poult. Sci. Sym., 14:35-43.

Bolu, SAO, Sola-Ojo, FE, Olorunsanya, OA, Idris, K. (2009). Effect of graded levels of Pawpaw Seed on the Performance, haematology and Serum biochemistry and Carcass evaluation of Broiler chickens. Asian Network for Scientific Information, Int. J. Poultry Sci., 8(9):905-909.

Doumas, BT, Briggs, HG. (1972). Serum Albumen Bromocresol Green Binding Standard Methods. Clin. Chem., 18(7):175-179.

Farmer, JJ. (2003). Enterobacteriaceae: Introduction and Identification, in Manual of Clinical Microbiology, 8th ed., Murray, P.R. et al., Eds., ASM Press, Washington, DC, chap. 41.

Hanan E. Al-Mashhadani (2014). Effect of different levels of turmeric supplementation on broiler performance, carcass characteristics and bacteria count of broiler chicken. Egyptian Poult. Sci. J., 35(1):25-39.

Harbone, JB. (1973). A guide to modern techniques to plant analysis. Chapman and hall, New York, USA 2nd Edition.

Ibrahim, NDG, Abdulrahman, EM, Ibrahim G. (2001). Elemental analysis of the leaves of Vernonia amydalina and its biological evaluation in rats. Nigerian J. Natural Product. Med., 5:13-17.

Igwe, CU, Onyeze, GOC, Onwuliri, VA, Osuagwu, CG, Ojiako, A0. (2010). Evaluation of the chemical composition of the leaf of Spondias mombin Linn from Nigeria. Aus. J. Basic Appl. Sci., 4(5):706-710.

Islam, MS, Lucky, NS, Islam, MR, Ahad, A, BR, Das, BR, Rahman, MM, Siddui, MSI. (2004). Hematological parameters of Fayoumi Assil and local chicken reared in sylhet region of Bangladesh. Int. J. Poult. Sci., 3(2):144-147.

Jain, NC. (1986). Schalms veterinary hematology $4^{\text {th }}$ edition Lea and Febiger, Philadelphia.

Jong, H, Ji, WL, Kyoung, SK, Ju-Sung, K, Sang, NH, Chang, YY, Ju, KL, Yong, SK, Myong, JK. (2010). Antioxidant and antimicrobial activities of extract from a medicinal plant. Sea Buckthorn. J. Kor. Soc. Appl. Bio. Chem., 53:33-38.

Mabhiza, D, Chitemerere, T, Mukanganyama, S. (2016). Antibacterial properties of alkaloids extracts from Callistemon citrinus and Vernonia adoensis against Staphylococcus aureus 


and Pseudomonas aeruginosa. Int. J. Med. Chem., 2016:1-7.
http://dx.doi.org/10.1155/2016/6304163

Madhusadhan, KT, Ranesh, HP, Ogawa, T, Sasoka, K, Singh, N. (1986). Detoxification of commercial linseed meal for use in broiler ration. Poultry Sci., 65:164-171.

Middleton, E, Kandaswani, C, Theoharides, TC. (2000). The effect of plant flavonoids on mammalian cells, implication for inflammation, heart disease and cancer. Pharmacol., 52:673-751.

Minka, NS, Ayo, JO. (2007). Physiological responses of transported goat treated with Ascorbic acid during hot dry season. Anim. Sci. J., 78(2):164-172.

Murray, RK, Granner, DK, Mayes, PA, Rodwell, VW. (2000). Harpers Biochemistry, 25 th edition, McGraw - Hill, Health Profession Division, USA, 225.

Naderi, M, Akbari, MR, Asadi-Khoshoei E, Khaksar K, Khajali F. (2014). Effect of dietary inclusion of Turmeric and curcurmon powders on the performance, organ relative weight and immune system parameters of broiler chicken. Poult. Sci. J., 2:153-163.

NRC, National Research Council (1994). Nutrient Requirement for Poultry (9 ${ }^{\text {th }}$ red) National Academy Press. Washington D. C, USA.

Obi, IU. (2002). Statistical methods for detecting differences between treatment means and research methodology issue in laboratory and field experiments. A.P. Company Limited., Nigeria.

Okaka, JC, Enoch, NJ, Okaka NC. (1992). Human Nutrition: An integrated approach ESUT Publications, Enugu, Pp: 57-58.

Panda, AK, Rao, SVR, Raju, MVLN, Sharma, SR. (2006). Dietary supplementation of Lactobacillus sporogenes on performance and serum biochemico-lipid profile of broiler chickens. J. Poult. Sci., 43(3):235-240.

Scott, HM. (1965). Measurement of Albino Acid content of fish meal protein by chick growth assay, P.Sc., pp: 395-65.

Shakeri, A, Hazeri, N, Vlizadeh, J, Ghasemi, A, Tavallaei, F. (2012). Phytochemical screening, antimicrobial and antioxidant activity of Anabasis aphylla L. extracts. Kregujevac J. Sci., 34:71-78.

Snedecor, GW, Cochran, WG. (1978). Statistical method $6^{\text {th }}$ edition Lowa State University press, Amen Lowa.

Snedecor, GW, Cochran, GW. (1978). Statistical methods $6^{\text {th }}$ edition, the IOWA University Press Ames, IOWA, USA. 258-299.

Soetan, KO, Olaiya, CO, Oyewole, OE. (2010). The importance of mineral elements for humans, domestic animals and plants: A review. African J. Food Sci., 4(5):200-222. 
Sofowora, A. (1993). Medicinal plants and Traditional Medicine in Africa. Spectrum Books Limited Ibadan. Nigeria. P: 289.

Talebi, A, Asri-Rezaei, S, Rozeh-Chai, R, Sahraei, R. (2005). Comparative studies on haematological values of broiler strains. Int. J. Poult. Sci., 4(8):573-579.

Tiwari, DP, Jyoti, P. (2008). Antibiotic Probiotic and Prebiotic as feed additives: Health benefits and safety. Food Quality Assurance: a concentrated approach p: 111-130.

Valerie, AS, Ibi, A, Toge, C, Amuzie UF, Ftepti BJ, Raji, B. (2017). Antimicrobial and physicochemical evaluation of L. aegyptiaca extracts. Biochem. Molecular Biology, 2(6):8085.

Vikas, K, Sinha, AK, Makka, HPS, Becker K. (2009). Dietary roles of phytate and phytase in human nutrition: A review. Food Chem., 120:945-959. www.elsevier.com/locate/foodchem

Watkins, BA, Kratzer, FH. (1983). Effect of oral dosing of Lactobacillus strains on gut colonization and liver biotin in broiler chicks. Poult. Sci., 62(10):2088-2094.

Wojdylo, A, Oszmianski, J, Czemerys, R. (2007): Antioxidant activity and phenolic compounds in 32 selected herbs. Food Chem., 105:940-949.

How to cite this article: J.O. Alagbe. Heamatology, Serum Biochemistry, Relative Organ Weight and Bacteria Count of Broiler Chicken Given Different Levels of Luffa Aegyptiaca Leaf Extracts. International Journal of Advanced Biological and Biomedical Research, 2019, 7(4), 370-380. Link: http://www.ijabbr.com/article 35677.html 